\title{
Innovations of Organic Agriculture, Challenges and Organic Certification in the United States
}

\author{
ZaDarreyal Wiggins $^{1} \&$ Dilip Nandwani ${ }^{1}$ \\ ${ }^{1}$ Department of Agriculture and Environmental Sciences, College of Agriculture, Tennessee State University, \\ Nashville, Tennessee, USA \\ Correspondence: Dilip Nandwani, Department of Agriculture and Environmental Sciences, College of \\ Agriculture, Tennessee State University, Nashville, Tennessee, USA.
}

Received: January 9, 2020 Accepted: February 13, 2020 Online Published: May 20, 2020

doi:10.5539/sar.v9n3p50

URL: https://doi.org/10.5539/sar.v9n3p50

\begin{abstract}
Organic agriculture is a production system that maintains the health of an agro-ecosystem by enhancing biodiversity and producing healthy soils by eliminating the use of chemicals. Other practices are used to enhance properties of the soil and increase long term soil fertility and prevent pest and diseases. Globally, organic agriculture has grown approximately by $20 \%$ yearly as consumers and growers make healthier food choices and show more concern about the impacts of our actions on the environment. Organic agriculture attempts to increase the level of food security and create a more sustainable environment for future generations. Organic certification has continuously increased as the benefits steady arise for farmers looking to produce healthier food. This article will observe the history, present day, challenges, certifications, impacts and benefits of the intriguing organic agricultural world.
\end{abstract}

Keywords: agriculture, biodegradable, biofertilizer, certification, innovative techniques, organic

\section{Introduction}

Organic agriculture's origin can be traced back to the early years of the twentieth century. Europe and the United States are perceived as the original pioneers with rich roots of organic agriculture that changed the view on agriculture, nutrition and food. Many farmers, scientists and consumers perceived organic farming as a paradigm shift in agriculture (Wynen, 1996). The pioneers of the early organic movement were inspired by a need to overturn the constant dilemmas of agriculture - erosion, soil depletion, decline of biodiversity, low quality food and livestock feed, and rural poverty. They welcomed a concept that the long-term effects of soil damage or health affects the overall health of a nation that is primarily focused on agriculture. The soil's health and vitality were believed to be embodied in its biology and in the organic soil fraction called humus (Heckman, 2006).

Over the previous few decades there has been an eventful change in the idea, movement and industry of organic agriculture. Around the early 1970s in the United States, a gathering of industrial growers and farmers began practicing organic farming, which at that time was a little-known and uncommon agricultural practice. They wanted to intervene into this new practice because they were convinced that there was something wrong with the commercial food model on a large production scale. During this time, majority of society was unaware of the new termed word "organic". Many were accustomed to conventional production, so it was very rare for consumers to shop organic food. Not only was the unawareness in society was high but a few scholars and scientists were frowned upon and disregarded for there interests in pursuing organic research. The United States government and federal scientists did not acknowledge the fresh practices of organic farming. The growth of organic agriculture has flourished into a multi-billion-dollar industry over the last four decades. Presently, there are isolated organic food sections located in various food supermarkets established all over the United States. According to Crowder and Reganold (Crowder and Reganold, 2015), seventy-five five percent of US consumers report buying organic products. Certified organic agricultural production area in the United States has increased steadily since the inception of the 1990 Organic Foods Production Act. Advantages of organic agriculture include economic benefits for producers.

The organic market reached $\$ 1$ billion by 1990 and increased to $\$ 28.6$ billion in 2010 . The table below shows the growth of U.S. Organic Food vs Total Food Sales from 2008 - 2017. Further proof that the organic market has expanded drastically, many public and private universities have created and devoted research and education 
directly towards organic agriculture. Furthermore, the federal government has completely adapted this practice because not only do they receive organic farming, but they have created federal standards that must be followed in order to be certified organic. The approval of organic production methods now produces foods that carry the official USDA seal. On several counts, the organic movement has been incredibly successful, arguably among the most effective movements of the late twentieth century (Obach, 2015).

Table 1. U.S. Organic Food vs. Total Food Sales, Growth and Penetration, 2008-2017

\begin{tabular}{|l|r|r|r|r|r|r|r|r|r|r|}
\hline Category & 2008 & 2009 & 2010 & 2011 & 2012 & 2013 & 2014 & 2015 & 2016 & 2017 \\
\hline Organic Food & 20,393 & 21.266 & 22,961 & 25.148 & 27.965 & 31,378 & 35,099 & 39.006 & 42.507 & 45,209 \\
\hline Growth (\%) & $17.5 \%$ & $4.3 \%$ & $8.0 \%$ & $9.5 \%$ & $11.2 \%$ & $12.2 \%$ & $11.9 \%$ & $11.1 \%$ & $9.0 \%$ & $6.4 \%$ \\
\hline Total Food & 659,012 & 669,556 & 677,354 & 713,985 & 740,450 & 760,486 & 787,575 & 807,998 & 812,907 & 822,160 \\
\hline Growth (\%) & $4.9 \%$ & $1.6 \%$ & $1.2 \%$ & $5.4 \%$ & $3.7 \%$ & $2.7 \%$ & $3.6 \%$ & $2.6 \%$ & $0.6 \%$ & $1.1 \%$ \\
\hline Organic (as \% Total) & $3.1 \%$ & $3.2 \%$ & $3.4 \%$ & $3.5 \%$ & $3.8 \%$ & $4.1 \%$ & $4.5 \%$ & $4.8 \%$ & $5.2 \%$ & $5.5 \%$ \\
\hline
\end{tabular}

Source: Organic Trade Association's 2018 Organic Industry Survey conducted 1/25/2018-3/36/2018 (Smil., consumer sales).

\section{Principles of Organic Agriculture}

Organic agriculture is production system that evades the use of synthetic pesticides and fertilizers, relies on biological pest control, and relies on crop rotation, green manure, compost, and other recycled wastes to maintain soil fertility (Goh, 2011). Improving the overall health of an agricultural ecosystem including the populations of plants, animals, soils, and humans is the ultimate objective of organic agriculture. Organic agriculture is based on certain principles as stated by Lynch (2009):

- Protect the environment, minimize soil degradation and erosion, decrease pollution, and optimize biological activity and health,

- Maintain soil fertility by optimizing conditions for biological activity within the soil,

- Maintain biological diversity within the system,

- Recycle materials and resources to the greatest extent possible within the enterprise, and

- Rely on renewable resources in locally produced organic food systems.

\section{Organic Agriculture and the Environment}

Soil degradation is a significant issue that continues to challenge organic agriculture. Tilling is a practice that is commonly used in many of the developed countries. It has many purposes but the main purpose for weed management and introducing and managing organic amendments (Barberi, 2006). Raviv (2010) reported that the most important field of research in organic horticulture should be the identification of novel and efficient methods for weed control that have no negative effects on system sustainability, especially on soil quality parameters such as soil humidity, soil pH, soil microbial activity, soil water holding capacity, etc. Raviv (2010) also believed that boosting tillage could balance the improved energy efficiency in an organic farming system.

Agriculture has the capability to alter nature's characteristics such as soil, water, air, flora, and topography. Environmental injury arises from agricultural mistakes like mishandling of pesticides and fertilizers, grouping large numbers of livestock in a small area, over tilling, and repetitive crop rotations. These issues can lead to soil degradation and desertification. Consequently, energy efficient strategies to control weeds need to be further developed, including no-till and reduced tillage cropping systems. However, if managed correctly, all of these negatives can reverse into positive impacts by diversifying the landscape and increasing biodiversity (Scherr and McNeely, 2008; Rahmann, 2011). Here, organic agriculture can play a significant role, much more progressive than conventional farming. Conventional farming requires a lot of enforcing and overlooking of agricultural practices, primarily with pesticides and fertilizers. Organic agriculture diminishes the threats of misuse of pesticides considerably. Also, by using organic and natural fertilizers, there is limited risks of fertilizer pollution. Animals and plants are relying on the environment, so it is imperative that agricultural events do not bring any neglect or harm but instead enhance the natural environment. 
Table 2. Shows the distinctive shift regarding the ideas and perception of conventional and organic farming (Nandwani, 2018)

\begin{tabular}{ll}
\hline Conventional Farming & Organic Farming \\
\hline Dependence & Independence \\
Competition & Community \\
Domination of nature & Harmony with nature \\
Specialization & Diversity \\
Exploitation & Restraint \\
\hline
\end{tabular}

\section{Challenges of Organic Agriculture}

Major challenges in organic crop production are as follows:

\subsection{Crop Yield}

Over the years, one of the primary challenges of an organic farming system has been conventional farming production consistently outperforming the organic production system. Past studies have shown a consistent disparity between organic and conventional yields due to meta analyses performed. Not long ago, a meta analyses report concluded an average lower yield in organic systems from 19\% to $25 \%$ across numerous crops (De Ponti et al., 2012; Ponisio et al., 2015; Seufert et al., 2012). A consistent lower yield in organic production could create hesitation of converting to organic because critics of organic agriculture can argue there is no rational reason to convert to organic if the yields are lower. With a growing population, critics can contend that conventional farming is more efficient with nearly $30 \%$ less land. Therefore, the unfarmed land can be used for environmental benefits and conservation (Baier, 2000; Asafu-Adjaye et al., 2015; Phalan et al. 2011; Trewavas, 2001). However, yield gains have not been plainly associated with increased land set aside for conservation at the global or regional scale, thus the yield/conservation tradeoff is likely a false narrative that does not accurately represent the complexity of an agricultural system (Kremen, 2015).

\subsection{Pest Management}

Integrated pest management (IPM) is one of the earliest large-scale promoted Sustainable Agricultural Practices (SAPs). According to (FAO, 2020), IPM "means the careful consideration of all available pest control techniques and subsequent integration of appropriate measures that discourage the development of pest populations and keep pesticides and other interventions to levels that are economically justified and reduce or minimize risks to human health and the environment." The use of cultural, mechanical, physical, and biological controls is preferred in organic IPM, instead of using chemical pesticides. Due to the growth of organic farming, many countries are adapting to this method not only economic benefits but also for sustainable crop production. Organic pesticides are a growing trend in the US. However, they do have several contrasts when compared to conventional pesticides. Some of the shortcomings are the lack of systemic activity, brief shelf life, generally only effective on immature insects, most require ingestion to be effective and can be costly.

\subsection{Disease Management}

Environmental and toxicity issues have surfaced due largely to mishandling and abusive use of many synthetic fungicides (Singh Gurjar et al., 2012). A growing consciousness about environmental contamination due to pesticides, human health and development of fungicide-resistant strains in plant pathogens has confronted the plant pathologists to pursue eco-friendly non-toxic organic compounds for replacing the suggested fungicides in recent years (Meena et al., 2013). Scientists have found out that countless compounds obtained from living organisms have discovered a use in crop protection. Organic agriculture only allows a few 'natural' compounds for managing pests and diseases such as copper which is applied as fungicide in apple, grape, potato, and tomato production. In the organic production of crops such as apple, grape, tomato, and potato, which are susceptible to severe fungal infections, copper is often used as one of the very few 'natural' fungicides permitted in organic agriculture. But as a heavy metal, copper is under debate in the organic sector (Nuijten et al., 2018). Being that it is under investigation, introducing resistant varieties has become the prominent lead strategy to replace copper.

The European project CO-FREE aimed to develop innovative methods, tools, and concepts for the replacement of copper to reduce the use of copper in organic farming systems, as it is considered harmful for the environment (Dagostin et al., 2011). According to Dagostin et al., it is shown that it is not easy to minimize copper use by replacement with alternative plant protection products, as they are often less effective than copper-based sprayings itself, causing a major negative economic impact in most production systems (De Wit, 2016). 
However, previous studies have shown that when new varieties are introduced to society, they often run into sizeable obstacles. These obstacles arise because of the lack of awareness of the new varieties from retailers and consumers, which is needed to open and sustain a market (Tamm et al., 2004; Speiser et al., 2013; Vanloqueren and Baret, 2008). For producers, disease resistance is an imperative trait needed. However, consumers, traders, and retailers are not as concerned as farmers due to the lack of knowledge that current varieties are not always robust. The reason disease management has never been a concern for consumers is because, through the use and availability of chemical pesticides, many demands were still met (Vanloqueren and Baret, 2008).

\section{Innovative Techniques}

\subsection{Organic Vertical Gardening}

Vertical gardening refers to any kind of construction and support structure for growing plants in an upwards direction effectively. When plants are grown vertically, it increases the options for garden creativity and production. Vertical gardening is an efficient way to utilize limited space. As more buildings go up, the availability of land decreases which can create a problem in the agricultural world. Vertical gardening can help neutralize this issue by maximizing the use of the limited space. There are 2 major categories that vertical gardens can be split into: green facades and living wall systems (Natarajan et al., 2015). Green facade is a vertical system that includes plants that climb up tall surfaces or objects once they are planted into the soil at the base of a wall. Not only will the plants use the wall for vertical support but can use other structures attached to the wall such as a trellis or cable. Living wall systems are containers, panels or planters that contain soil or medium for plants to grow in, that are attached along a wall (Natarajan et al., 2015). Vertical gardening has many advantages. From a maintenance standpoint, the advantages could include reducing disease problems by being elevated from the ground surface, by increasing the air circulation through the foliage, and also making it easy to detect pests. Plus, growing crops vertically makes harvesting much easier because the plants are eye level and easier to reach versus bending over numerous times for crops that are traditionally planted in the soil. There is no definite, set structure to create a vertical gardening system and this allows for creativity when designing. These systems can be made from fences, cages, ladders, hanging baskets, and many other types of structures.

\subsection{Microbial Bio-fertilizers}

Biofertilizers has been acknowledged as a substitute to chemical fertilizers to increase soil fertility and crop production in sustainable farming. Biofertilizer is a substance comprised of living microorganisms which, when applied to seed, plant surfaces or soil, inhabits the rhizosphere or the interior of the plant and stimulates growth by increasing the supply or availability of primary nutrients to the host plant (Vessey, 2003). A few of the new, common biofertilizers currently being used are rhizobium, azotobacter, azospirillum, cyanobacteria, azolla, phosphate solubilizing microorganism, arbuscular mycorrhiza, silicate solubilizing bacteria and rhizobacteria. Many of these biofertilizers help with nitrogen fixation and others help by serving as bioprotectants or biostimulants for plants. Phosphorus availability can also be improved, although the efficacy can vary depending on crop species, formulation, soil amendments, soil $\mathrm{pH} / \mathrm{type}$, and weather conditions.

\subsection{Aeroponics}

Aeroponics is an agricultural system that produces plants with the lack of soil. Aeroponics offers an effective method to produce plants, including fruits and vegetables, without potting and repotting them to replace their access to nutrient-rich soil. Plants are placed in soilless growing media frames that leaves the roots suspended in the air. Nutrients are provided to the suspended roots via air and mist. There are many types of aeroponic systems and depending on the system, nutrients can be manually or automatically applied. Most aeroponic systems possess one or more pumps that can be programmed to automatically nourish the plants without heavy supervision. Aeroponics do provide advantages over traditional soil grown crops. One benefit of this system is the capability of growing vertically and horizontally depending on space availability. Another advantage is the noticeable decrease in labor intensity (Buckseth et al., 2016). Without having to prepare soil and testing for the right qualities needed, most of the labor for aeroponics comes from harvest. Lastly, two of the more pertinent advantages is the ability to extend growing seasons and reduce pest and disease thresholds. However, there are a few disadvantages, but the higher concern would be the cost of startup and maintenance on an aeroponic system, as they can be costly depending on complexity.

\subsection{Biodegradable Mulches}

Biodegradable plastic mulch (plastic BDM) provides crop production benefits parallel to polyethylene (PE) mulch but it conserves time and energy by being able to be tilled into the soil once harvest is completed (Ghimire et al., 2018). Plastic BDMs offer a likely solution to disposal and environmental issues linked with PE 
mulch use. However, weed management and durability are the key factors that must be comparable or excel PE in order to be a viable alternative for organic crop production (Ghimire et al., 2018). Plastic BDMs are mostly produced from natural raw materials that can be considered biobased, derived from fossil fuels or a combination of the two. Recently, there have been some studies that have researched the biodegradability and effectiveness of plastic BDMs. The studies so far are promising but are still in the early stages.

\subsection{Cover Crops}

Cover crops have often been used in the past but today their popularity is steady increasing. In the past, it was well known that cover crops help replenish nutrients in the soil for cash crops to be grown but today cover crops are used to provide a variety of functions. As more and more research has been done, cover crops have been found to have many functions, many of which are connected to cover crop efficiency. These functions include weed suppression, soil nutrient retention, soil erosion control, and organic matter addition. The incorporation of diverse cover crop varieties is a new trend that has been found to have a positive effect. This is important because in past years, farmers have used the same cover crop annually, but this new discovery could bring forth new practices. Cover crops that possess allelopathic properties have been linked to the suppression of weeds which can limit the amount of labor hours used for weed management. Also, it is obvious how important organic matter is in an organic system, so having diverse cover crops that can be till into the soil will increase the organic matter composition.

\section{Organic Certification}

Being USDA organic certified has huge implications in the market. However, many consumers are not aware of the levels of organic certification. There are different levels of USDA organic certification. Certified products with $100 \%$ organic ingredients can say $100 \%$ Organic and display the USDA Organic seal. Certified products with 95\% organic ingredients can say Organic and display the USDA Organic seal. Certified products with a minimum of $70 \%$ organic ingredients can say "Made with Organic Ingredients" but may not display the USDA Organic seal. Products made with less than $70 \%$ organic ingredients, or products that are not certified, can only list individual ingredients that are organic in the product's ingredient statement. The required ingredient list is the only place the word "organic" can appear on the entire package for these products (Connolly, 2015).

\section{Number of Certified Organic Farms by State, 2016}

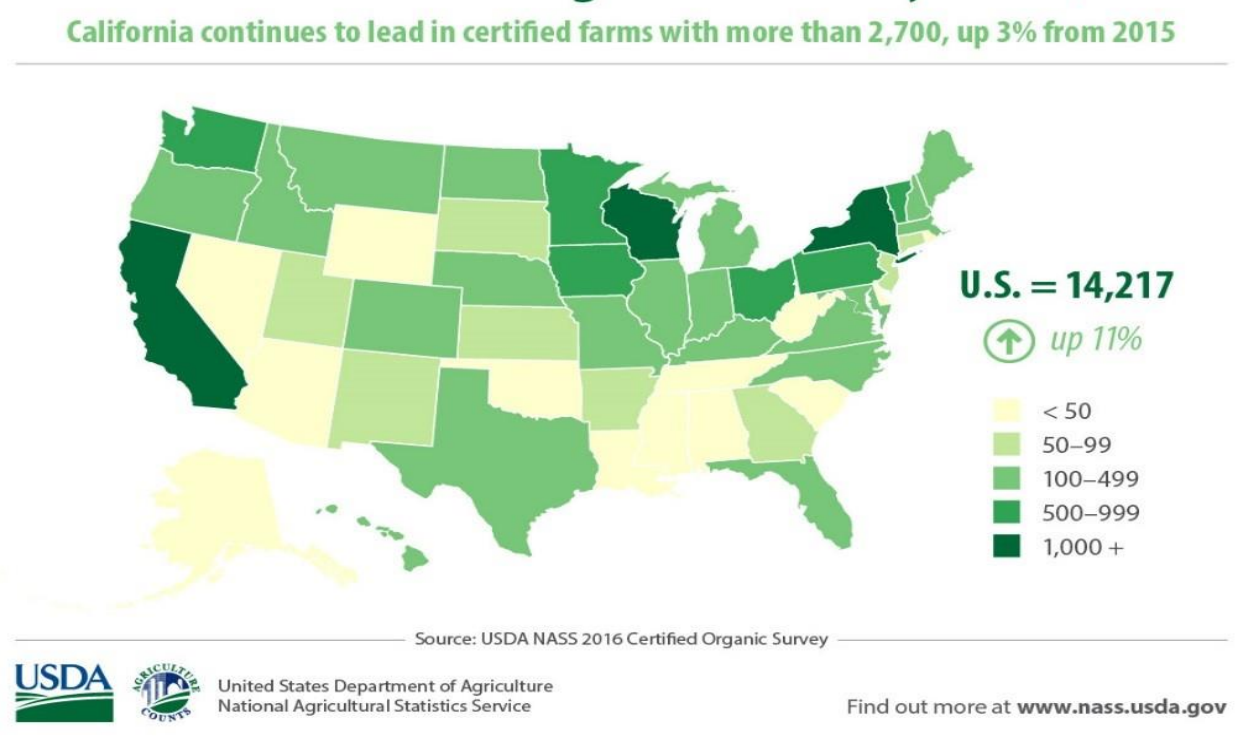

Figure 1. Number of Certified Organic Farms by State, 2016

\subsection{Benefits of Organic Certification}

One of the fastest growing agricultural sectors has been organic agriculture. This industry has provided the US with economic growth, creating jobs and agricultural awareness. Figure 1 shows the certified organic growth in the United States over the last few years. Becoming organic certified has its perks and benefits. Many farmers 
and growers proudly promote their organic certification once the certification process has been completed. The USDA Organic seal can be placed anywhere on the product or packaging once certification has been obtained. Furthermore, sometimes when it comes to marketing, the organic seal is the only marketing tool needed in order to get consumers interested. The desire for organic products has been and continues to thrive and become more popular.

Consumers are constantly pursuing products that are organic, healthy, natural and good quality. Not only are the products a marketing tool but consumers knowing that a producer is openly using organic, high quality production techniques to produce better products will draw the attention of the growing organic society. Spotting "Organic" on a food package is a massive attraction for this audience. If a product is not certified organic, which means "organic" can only be used in the ingredient listing, many buyers will not realize the product has an organic association. According to (Connolly, 2015) about 25 percent of consumers browse the ingredients of a product and recognize that organic ingredients were used to make the product. If that is the case, then there is nearly $75 \%$ of unaware buyers that are not knowing the organic certification importance of your product, which is a big economic disparity. This is important because consumers are willing to pay more for organic labeled products. There are many factors that can influence this decision such as peace of mind knowing how the product was produced, wanting a healthier lifestyle, looking for a different taste or type of food, desiring to help protect the environment and others.

Customers know that organic brands are united with a healthy lifestyle and care for the environment. In the big picture, customers know that harmful ingredients are not used if the product is labeled organic. Some will take a quick glance at the ingredient list to confirm no harmful ingredients have been used. When a brand makes a product that is well trusted by consumers, they are not just buying that particular product. The brand gains trust and able to get consumers to buy into the brand, not just the organic product, which means they will be inspired to purchase other items made from that particular brand (Connolly, 2015)

\subsection{Organic Certification Process}

The major steps involved in the certification process under the USDA NOP are highlighted below (Nandwani, 2018):

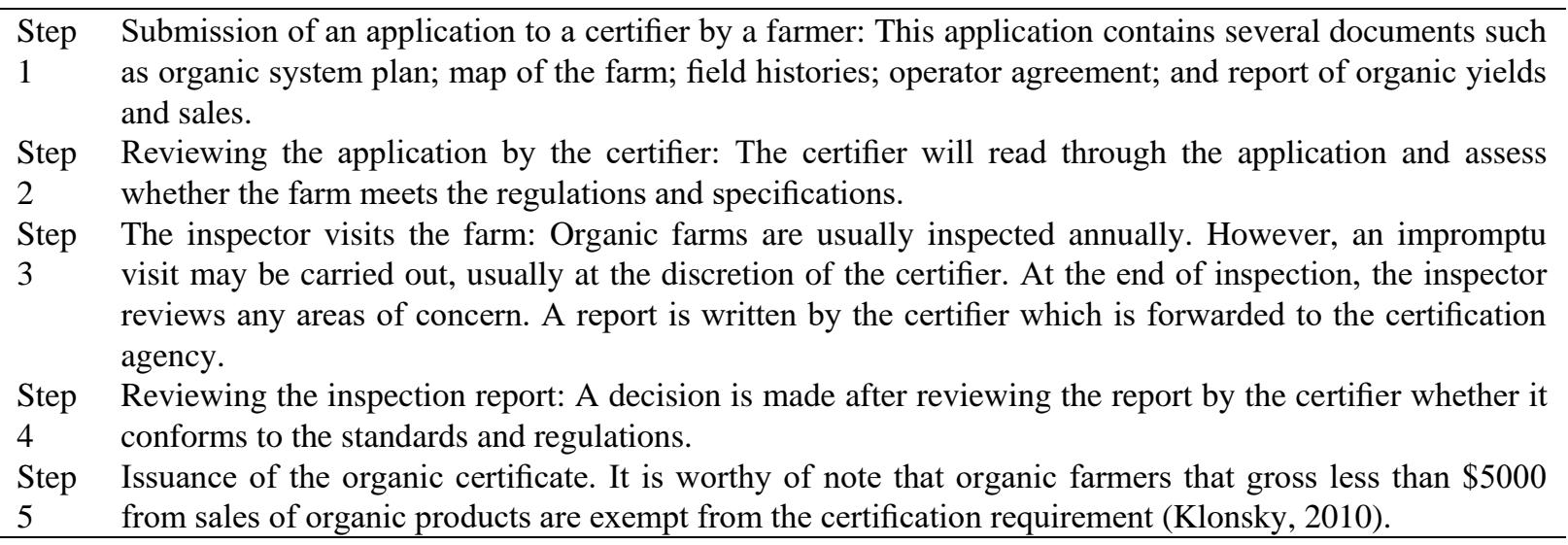

\subsection{Future of Organic Production}

Diversification is a key agroecological principle of organic agriculture. Diversification in organic agriculture provides positive outcomes including increase biodiversity, pollination, pest management, soil fertility, disease management, and yield stability. It is believed that demand for organic foods will continue to increase, therefore larger and more organic farms will be needed. In areas where organic agriculture is thought of as superior and worthy, farmers will benefit from the premium prices and consumers will be pleased with the organic products. In food secure developed countries, organic farming will serve a great food production significance. For underdeveloped countries, organic agriculture could be a good fit due to synthetic chemicals being too expensive. As far as organic production in the US, a consistent rise has been the trend for almost 2 decades and is anticipated to continue that tendency.

\section{References}

Asafu-Adjaye, J., Blomqvist, L., Brand, S., Brook, B., Defries, R., Ellis, E., Foreman, C., Keith, D., Lewis, M., ... Lynas, M. (2015). An Ecomodernist Manifesto. 
Baier, C. (2000). Saving the Planet with Pesticides and Plastic: A Critical Review.

Barberi, P. (2006). Special topic 4; Tillage: how bad is it in organic agriculture? In P. Kristiansen, A. Taji \& J. Reganold (Eds.), Organic Agriculture a Global Perspective (pp. 295-303). CSIRO Publishing. https://doi.org/10.1079/9781845931698.0295xianwei Ma

Buckseth, T., Sharma, A. K., Pandey, K. K., Singh, B. P., \& Muthuraj, R. (2016). Methods of pre-basic seed potato production with special reference to aeroponics-A review. Sci Hortic (Amsterdam), 204, 79-87. https://doi.org/10.1016/j.scienta.2016.03.041

Connolly, J. D. (2015). Is Organic Certification Worth It? | Jenn David Design. Jenn David Des. Retrieved from https://jenndavid.com/is-organic-certification-worth-it/

Crowder, D. W., \& Reganold, J. P. (2015). Financial competitiveness of organic agriculture on a global scale. Proc Natl Acad Sci U S A. 112(24), 7611-7616. https://doi.org/10.1073/pnas.1423674112

Dagostin, S., Schärer, H. J., Pertot, I., \& Tamm, L. (2011). Are there alternatives to copper for controlling grapevine downy mildew in organic viticulture? Crop Prot., 30(7), 776-788. https://doi.org/10.1016/j.cropro.2011.02.031

FAO. (2020). Plant Production and Protection Division: Integrated Pest Management. Food Agric Organ United Nations. Retrieved from http://www.fao.org/agriculture/crops/thematic-sitemap/theme/pests/ipm/en/.

Ghimire, S., Hayes, D., Cowan, J. S., Inglis, D., DeVetter, L. W., \& Miles, C. A. (2018). Biodegradable Plastic Mulch and Suitability for Sustainable and Organic Agriculture.

Goh, K. M. (2011). Greater mitigation of climate change by organic than conventional agriculture: A review. Biol Agric Hortic., 27(2), 205-229. https://doi.org/10.1080/01448765.2011.9756648

Heckman, J. (2006). A history of organic farming: Transitions from Sir Albert Howard's War in the Soil to USDA National Organic Program. Renew Agric Food Syst., 21(3), 143-150. https://doi.org/10.1079/RAF2005126

Klonsky, K. (2010). A Look at California's Organic Agriculture Production. 14(2), 8-11.

Kremen, C. (2015). Reframing the land-sparing/land-sharing debate for biodiversity conservation. Ann N Y Acad Sci., 1355(1), 52-76. https://doi.org/10.1111/nyas.12845

Meena, P. D., Gour, R. B., Gupta, J. C., Singh, H. K., Awasthi, R. P., Netam, R. S., Godika, S., Sandhu, P. S., Prasad, R., ... Rathi, A. S. (2013). Non-chemical agents provide tenable, eco-friendly alternatives for the management of the major diseases devastating indian mustard (brassica juncea) in india. Crop Prot., 53, 169-174. https://doi.org/10.1016/j.cropro.2013.07.006

Nandwani, D. (2018). Organic farming for sustainable agriculture. In D. Nandwani \& S. Nwosisi (Eds.), Organic Farming for Sustainable Agriculture (pp. 21). SPRINGER.

Natarajan, M., Rahimi, M., Sen, S., Mackenzie, N., \& Imanbayev, Y. (2015). Living wall systems: evaluating life-cycle energy, water and carbon impacts. Urban Ecosyst., 18(1), 1-11. https://doi.org/10.1007/s11252-014-0378-8

Nuijten, E., de Wit, J., Janmaat, L., Schmitt, A., Tamm, L., \& Lammerts, van B. E. T. (2018). Understanding obstacles and opportunities for successful market introduction of crop varieties with resistance against major diseases. Org Agric., 8(4), 285-299. https://doi.org/10.1007/s13165-017-0192-8

Obach, B. K., \& Brian, K. (2015). Organic struggle: the movement for sustainable agriculture in the United States. https://doi.org/10.7551/mitpress/9780262029094.001.0001

Phalan, B., Onial, M., Balmford, A., \& Green, R. E. (2011). Reconciling food production and biodiversity conservation: Land sharing and land sparing compared. Science, 333(6047), 1289-1291. https://doi.org/10.1126/science.1208742

Ponisio, L. C., M'gonigle, L. K., Mace, K. C., Palomino, J., Valpine, P. De, \& Kremen, C. (2015). Diversification practices reduce organic to conventional yield gap. Proc $R$ Soc B Biol Sci., 282(1799). https://doi.org/10.1098/rspb.2014.1396

De Ponti, T., Rijk, B., \& Van Ittersum, M K. (2012). The crop yield gap between organic and conventional agriculture. Agric Syst., 108, 1-9. https://doi.org/10.1016/j.agsy.2011.12.004

Rahmann, G. (2011). Biodiversity and Organic farming: What do we know? 
Raviv, M. (2010). Sustainability of Organic Horticulture. In: Horticultural Reviews. John Wiley \& Sons, Inc. p. 289-333. https://doi.org/10.1002/9780470527238.ch6

Scherr, S. J., \& McNeely, J. A. (2008). Biodiversity conservation and agricultural sustainability: Towards a new paradigm of "ecoagriculture" landscapes. Philos Trans R Soc B Biol Sci., 363(1491), 477-494. https://doi.org/10.1098/rstb.2007.2165

Seufert, V., Ramankutty, N., \& Foley, J. A. (2012). Comparing the yields of organic and conventional agriculture. Nature., 485(7397), 229-232. https://doi.org/10.1038/nature11069

Singh, G. M., Ali, S., Akhtar, M., \& Singh, K. S. (2012). Efficacy of plant extracts in plant disease management. Agricultural Sciences, 3(3), 425-433. http://dx.doi.org/10.4236/as.2012.33050

Speiser, B., Stolze, M., Oehen, B., Gessler, C., Weibel, F., Bravin, E., Kilchenmann, A., ... Lang, A. (2013). Sustainability assessment of GM crops in a Swiss agricultural context. Sus-tainability assessment of GM crops in a Swiss agricultural context. Agronomy for Sustainable Devel-opment Sustainability assessment of GM crops in a Swiss agricultural context. Agron Sustain Dev., 2012(1), 21-61. https://doi.org/10.1007/s13593-012-0088-7ï

Tamm, L., Häseli, A., Fuchs, J. G., Weibel, F. P., \& Wyss, E. (2004). Organic Fruit Production in Humid Climates of Europe: Bottlenecks and New Approaches in Disease and Pest Control. Acta Hortic., 638, 333-339. https://doi.org/10.17660/ActaHortic.2004.638.44

Trewavas, A. (2001). Urban myths of organic farming. Nature., 410(6827), 409-410. https://doi.org/10.1038/35068639

Vanloqueren, G., \& Baret, P. V. (2008). Why are ecological, low-input, multi-resistant wheat cultivars slow to develop commercially? A Belgian agricultural "lock-in" case study. Ecol Econ., 66(2-3), 436-446. https://doi.org/10.1016/j.ecolecon.2007.10.007

Vessey, J. K. (2003). Plant growth promoting rhizobacteria as biofertilizers. Plant Soil, 255(2), 571-586. https://doi.org/10.1023/A:1026037216893

De Wit, J. (2016). Strategies to replace copper-based products as plant protection in low input and organic farming systems.

Wynen, E. (1996). Research Implications of a Paradigm Shift in Agriculture: The Case of Organic Farming.

\section{Copyrights}

Copyright for this article is retained by the author(s), with first publication rights granted to the journal.

This is an open-access article distributed under the terms and conditions of the Creative Commons Attribution license (http://creativecommons.org/licenses/by/3.0/). 